\title{
PERANCANGAN SISTEM INFORMASI PELANGGAN PASIEN PADA RUMAH SAKIT JIWA (RSJ) ACEH
}

\author{
Hawilah Anggrainy \\ Mahasiswa Program Studi Manajemen Informatika, Fakultas Ilmu Komputer, \\ AMIK Indonesia, Jl. T Nyak Arief Sp Mesra No. 400, Kota Banda Aceh, Indonesia \\ Email: hawilah.anggrainy_cutbi@gmail.com
}

\begin{abstract}
Abstrak
Tujuan penelitian yaitu; Untuk mengetahui Sistem Informasi Pasien pada Rumah Sakit Jiwa (RSJ) Aceh dan Merancang Sistem Informasi Pasien pada Rumah Sakit Jiwa (RSJ) Aceh menggunakan Visual BASIC.NET. Secara garis besar penelitian ini dibagi dalam tiga tahapan, yaitu pengumpulan data pra pengembangan, pengembangan serta implementasi, dan pengumpulan data pasca Pengembangan. Sedangkan dalam pengembangan perangkat lunak menggunakan metode DSRM (Design Science Research Method). Dengan adanya Program Sistem Informasi pasien ini Sistem informasi pada Rumah Sakit Jiwa (RSJ) Aceh menjadi tepat, dan akurat khususnya pada bagian pasien. Dan untuk memperoleh informasi mengenai pasien tersebut menjadi lebih mudah; Sistem informasi ini mampu mengatasi permasalahan yang sering terjadi pada Rumah Sakit Jiwa (RSJ) Aceh yaitu sulit dalam mengontrol dan mengawasi pasien dan perencanaan pengadaan barang. sistem informasi pengadaan barang ini dapat menghindari pasien berlebih dan mengatasi kelangkaan barang yang tentunya sangat di harapkan oleh pelaku usaha dan Terciptanya suatu program sistem informasi guna untuk memperoleh informasi yang berkualitas.
\end{abstract}

Kata Kunci: Sistem Informasi; Rumah Sakit; Visual BASIC.NET.

\begin{abstract}
The research objectives are; To find out the Patient Information System at the Aceh Mental Hospital (RSJ) and Design a Patient Information System at the Aceh Mental Hospital (RSJ) using Visual BASIC.NET. Broadly speaking, this research is divided into three stages, namely pre-development data collection, development and implementation, and post-development data collection. While in software development using the DSRM (Design Science Research Method) method. With the existence of this patient information system program, the information system at the Aceh Mental Hospital (RSJ) becomes precise, and accurate, especially on the patient side. And to obtain information about the patient becomes easier; This information system is able to overcome the problems that often occur in the Aceh Mental Hospital (RSJ), namely the difficulty in controlling and supervising patients and planning for procurement of goods. This goods procurement information system can avoid excess patients and overcome the scarcity of goods which is certainly highly expected by business actors and the creation of an information system program in order to obtain quality information.
\end{abstract}

Keyword: Information Systems; Hospital; Visual BASIC.NET. 


\section{Pendahuluan}

Rumah Sakit Jiwa (RSJ) berada di daerah Kota Banda Aceh Provinsi Aceh yang merupakan salah satu pusat kesehatan yang ada di daerah tersebut. Semakin berkembangnya masyarakat di lingkungan sekitar dan bahkan masyarakat dari luar daerah yang terus berdatangan untuk berobat di rumah sakit Rumah Sakit Jiwa (RSJ) membutuhkan suatu pelayanan yang baik kepada pasien dengan dukungan tenaga medis dan para staff yang baik di harapkan mampu memberikan pelayanan kesehatan secara profesional hal ini tentunya tidak lepas dari manajemen sistem yang ada di rumah sakit tersebut.

Tenaga medis dan staff yang mampu memberikan pelayanan dengan baik kepada konsumen tentunya harus di dukung dengan pengolahan data-data [1,2] yang ada guna memperlancar hasil laporan yang ada itulah yang menjadi permasalahan di Rumah Sakit Jiwa (RSJ) di antaranya adalah sistem pendataan pasien yang masih menggunakkan pembukuan baik proses pencatatan data pasien maupun proses pengarsipan data $[3,4]$ untuk di jadikan laporan yang kurang begitu efektif sehingga informasi yang akan di sampaikan tidak berjalan secara optimal $[5,6]$.

Pendataan pasien yang masih mengunakan pembukuan sering terjadi banyak kesalahan di antaranya petugas yang ada sering lupa menginputkan data-data untuk di jadikan laporan kepada pimpinan dan tingkat ketelitian juga masih di ragukan $[7,8]$. Selain hal-hal tersebut petugas yang ada sering lupa menyimpan data-data para pasien, sehingga proses pencarian data terhambat hal ini tentunya juga salah satu penghabat arus informasi pada mulanya hal itu bukan suatu masalah bagi pihak rumah sakit namun di saat pasien perharinya makin bertambah banyak maka pihak rumah sakit merasa kewalahan dalam hal mengolah data-data para pasien. Dari uraian diatas maka yang menjadi tujuan pembahasan yaitu; 1) Untuk mengetahui Perancangan Sistem Informasi Pasien pada Rumah Sakit Jiwa (RSJ), dan 2) Merancang Perancangan Sistem Informasi Pasien pada Rumah Sakit Jiwa (RSJ) menggunakan Visual BASIC.NET.

\section{Metode Penelitian}

Pengumpulan data yang diperlukan dalam penulisan penelitian ini diperoleh dengan dua metode yaitu studi kepustakaan yang berkaitan dengan literatur-literatur buku-buku perpustakaan dan karya ilmiah lainnya, studi lapangan dengan melaksanakan interview dan observasi langsung terhadap objek yang berhubungan dengan penelitian ini $[9,10,11]$. Secara garis besar penelitian ini dibagi dalam tiga tahapan, yaitu pengumpulan data pra pengembangan, pengembangan serta implementasi, dan pengumpulan data pasca Pengembangan [12,13]. Sedangkan dalam pengembangan perangkat lunak menggunakan metode DSRM (Design Science Research Method) [14]. Adapun penjelasan detail untuk tahapan penelitian adalah seperti dijelaskan pada gambar 1 berikut.

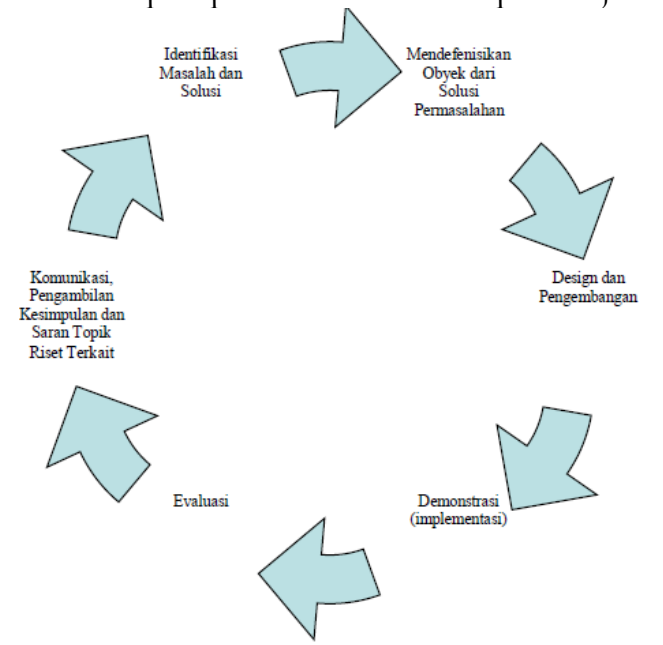

Gambar 1. Metode DSRM (Design Science Research Method) [14]. 


\section{Hasil dan Pembahasan}

Analisa merupakan tahap yang menemukan teknik penguraian komponen-komponen untuk mencapai suatu tujuan, setelah kebutuhan dari suatu permasalahan telah teridentifikasi [15], studi kelayakan terpenuhi hingga batasan-batasan analisis terhadap yang akan di implementasikan ke dalam suatu pemograman [16, 17]. Analisis dilakukan untuk memperoleh informasi tentang yang sedang berjalan dibidang administrasi dimana informasi yang dikumpulkan terutama mengenai kelebihan dan kekurangan yang berlaku sehingga nantinya dapat menghasilkan informasi baru yang efektif dan efisien [15,17].

Pada tahap ini juga di uraikan tentang beberapa prosedur atau tahap dalam menjalankan pasien dilengkapi dengan FlowMap tentang yang sedang berjalan dan usulan pada Rumah Sakit Jiwa (RSJ) Aceh. FlowMap merupakan bangan arus yang menunjukkan struktur umum dari sebuah informasi, yang menampilkan uraian umum urutan pemprosesan data dalam bentuk umum dan menunjukkan arus pekerjaan secara keseluruhan. Berdasarkan hasil pengamatan langsung pada Rumah Sakit Jiwa (RSJ) Aceh. Sistem yang sedang berjalan pada Rumah Sakit Jiwa (RSJ) Aceh sampai saat ini sudah menggunakan sistem secara terkomputerisasi, terutama dalam melakukan penginputan data pasien tetapi hanya pada penggunaan aplikasi Microsoft Office Excell. Rumah Sakit Jiwa (RSJ) Aceh saat ini telah memiliki sebuah komputer sebagai alat bantu, tetapi komputer tersebut hanya digunakan untuk melakukan pengetikan surat dan tidak untuk melakukan penginputan data untuk pasienbaru dikarenakan tidak adanya aplikasi yang mendukung pada komputer tersebut. Setelah diadakan pengamatan dan interview dari sistem yang sedang berjalan diperoleh beberapa prosedur sistem yang sedang berjalan yaitu :

\section{Prosedur Pendaftaran (Registration) Pasien baru.}

Pendaftaran pasien baru adalah proses pendaftaran calon pasien baru yang akan melakukan pelayanan pemeriksaan di rumah sakit. Pendaftaran pasien baru ini dilakukan oleh petugas pendaftaran (Registration):

a) Pasien mengisi formulir pendaftaran pasien baru dan memberikan formulir tersebut kepada petugas pendaftaran (Registration).

b) Petugas pendaftaran membuat dan menyiapkan Map Medical Record yang berisi kartu berobat, nota pemeriksaan dan buku rekam medis yang akan diberikan kepada pasien dan poliklinik.

c) Pasien memilih poliklinik yang akan dituju.

d) Pasien akan melakukan pemeriksaan. Kartu berobat dan nota transaksi diberikan kembali ke pasien. 


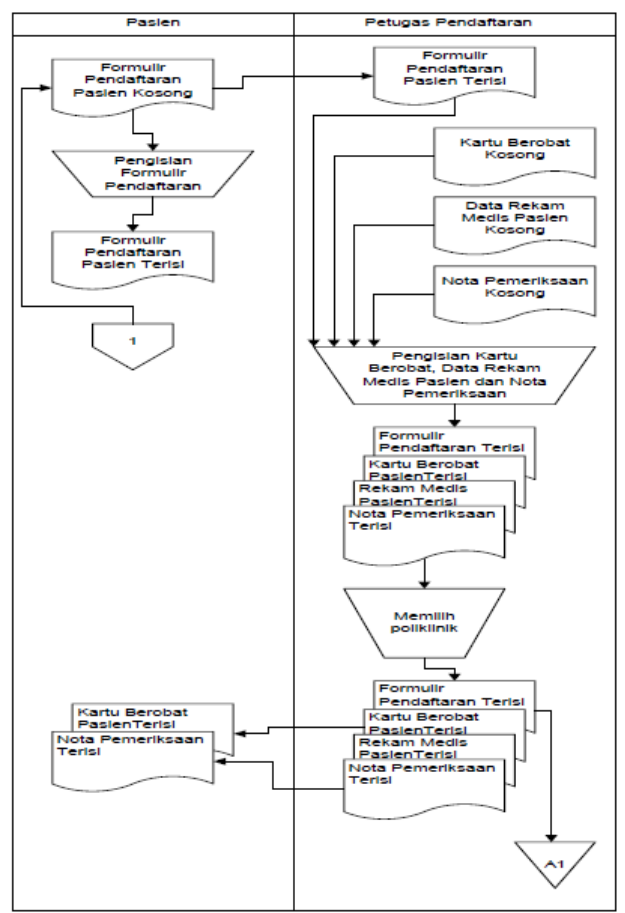

Gambar 2. FlowMap Berjalan Pendaftaran Pasien

\section{Prosedur Antrian Pasien Rawat Jalan}

Antrian pasien rawat jalan adalah proses dimana pasien menunggu dan mengantri untuk melakukan pemeriksaan rawat jalan.

a) Pasien menunggu di poliklinik yang telah dipilih.

b) Petugas pendaftaran menyerahkan Map Medical Record kepada polikllinik yang dituju.

c) Petugas poliklinik mencatat data pasien dan rekam medis pasien untuk poliklinik yang dituju.

d) Petugas poliklinik mengelola Map Medical Record untuk melakukan pemeriksaan rawat jalan.

e) Pasien mengantri di poliklinik untuk menunggu panggilan pemeriksaan rawat jalan pasien.

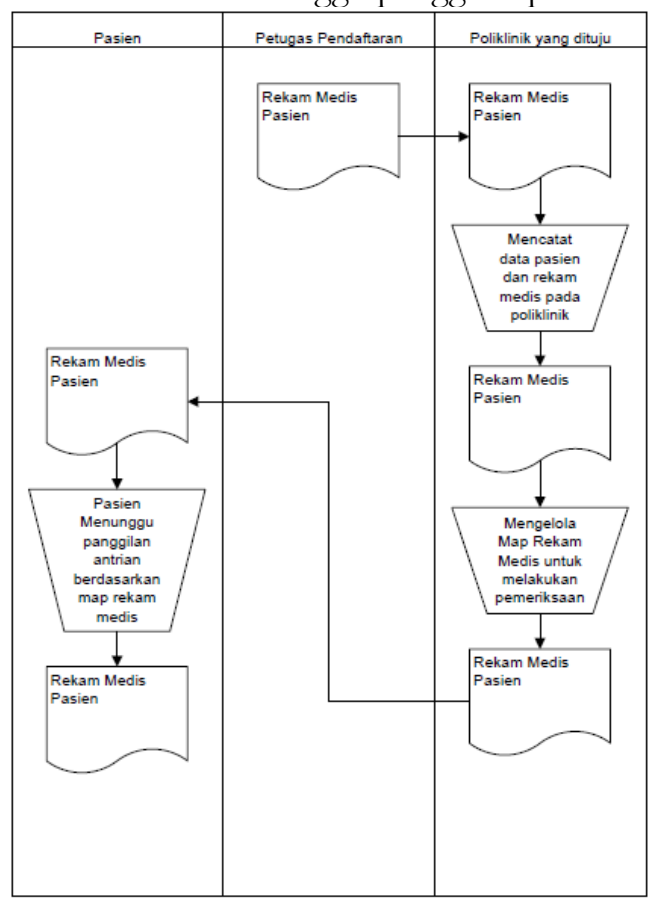

Gambar 3. FlowMap Berjalan Rekam Medis Pasien Rawat Jalan 
Perancangan sistem merupakan suatu kegiatan pengembangan prosedur dan proses yang sedang berjalan untuk menghasilkan suatu sistem yang baru, atau memperbaharui sistem yang ada untuk meningkatkan efektifitas kerja agar dapat memenuhi hasil yang digunakan dengan tujuan memanfaatkan teknologi dan fasilitas yang tersedia. Pada bab ini penulis akan memberikan usulan yang merupakan sistem informasi secara komputerisasi yang diharapkan dapat membantu dan mempermudah pekerjaan.

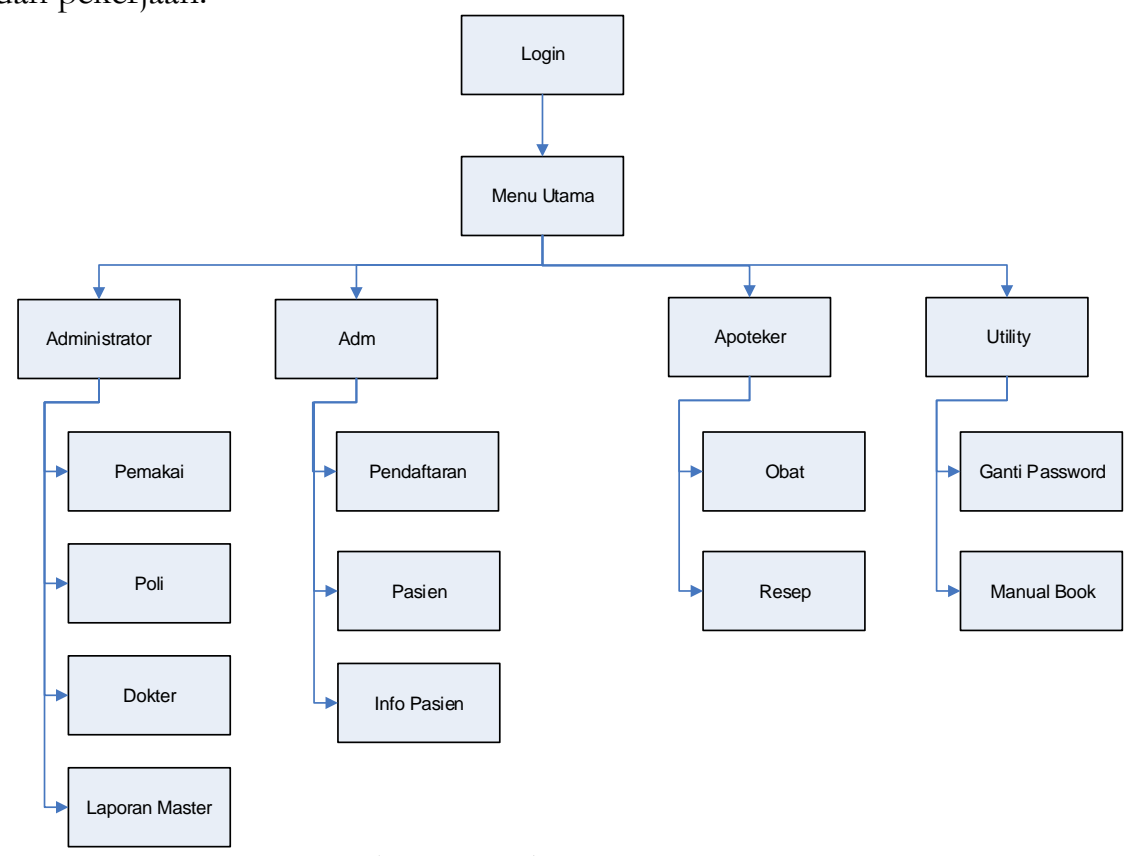

\section{Unifed Model System (UML)}

Gambar 4. Struktur Menu Program

Analisa proses bertujuan untuk mengetahui proses persediaan barang dan produksi Rumah Sakit Jiwa (RSJ) Aceh. Analisa proses ini dapat dilihat dari activity diagram sistem yang berjalan berikut ini.

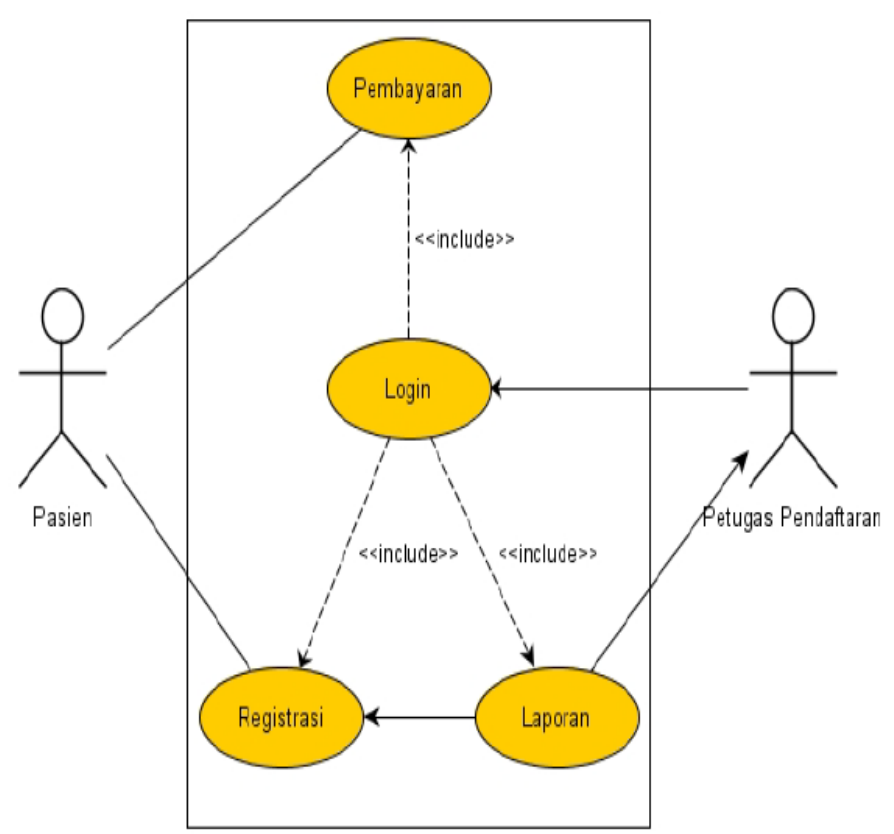

Gambar 5. Activity Diagram Pendaftaran Pasien 
Jurnal Indonesia : Manajemen Informatika dan Komunikasi

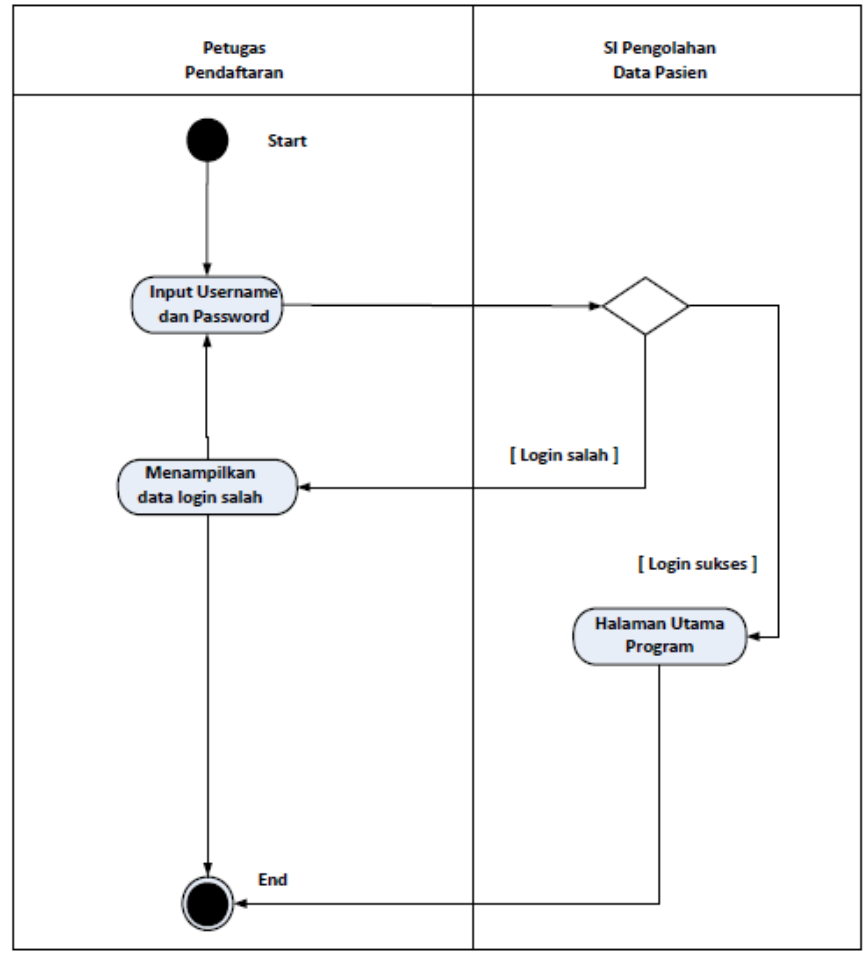

Gambar 6. Use Case Pendaftaran Pasien

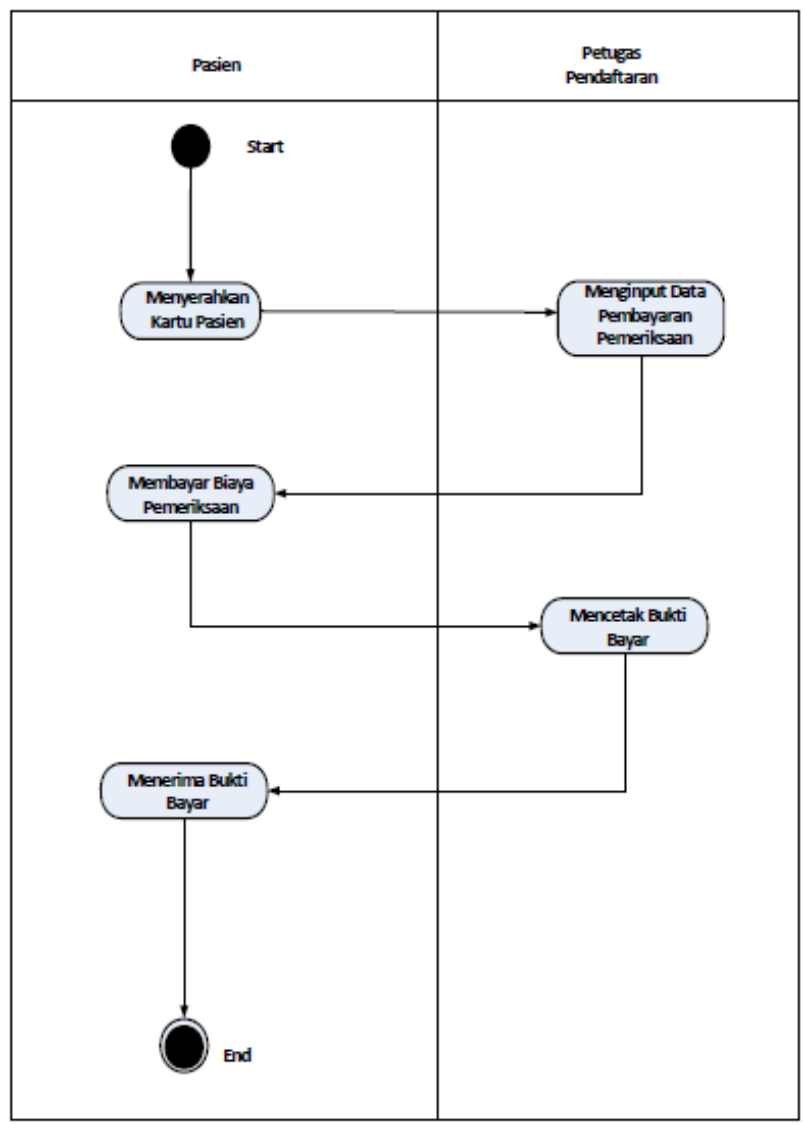

Gambar 7. Activity Diagram Pembayaran 


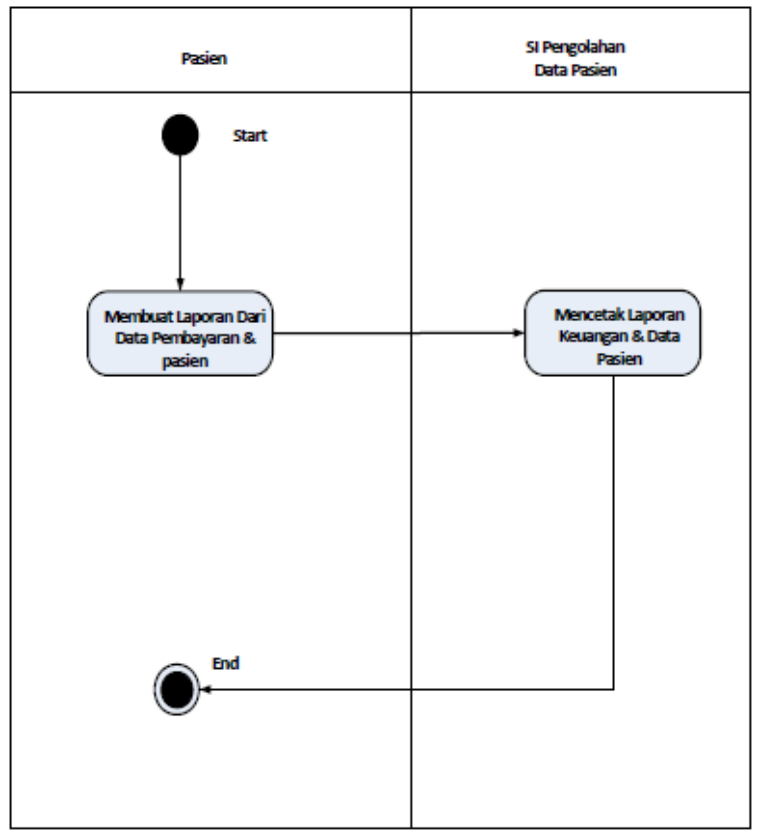

Gambar 8. Activity Diagram Laporan

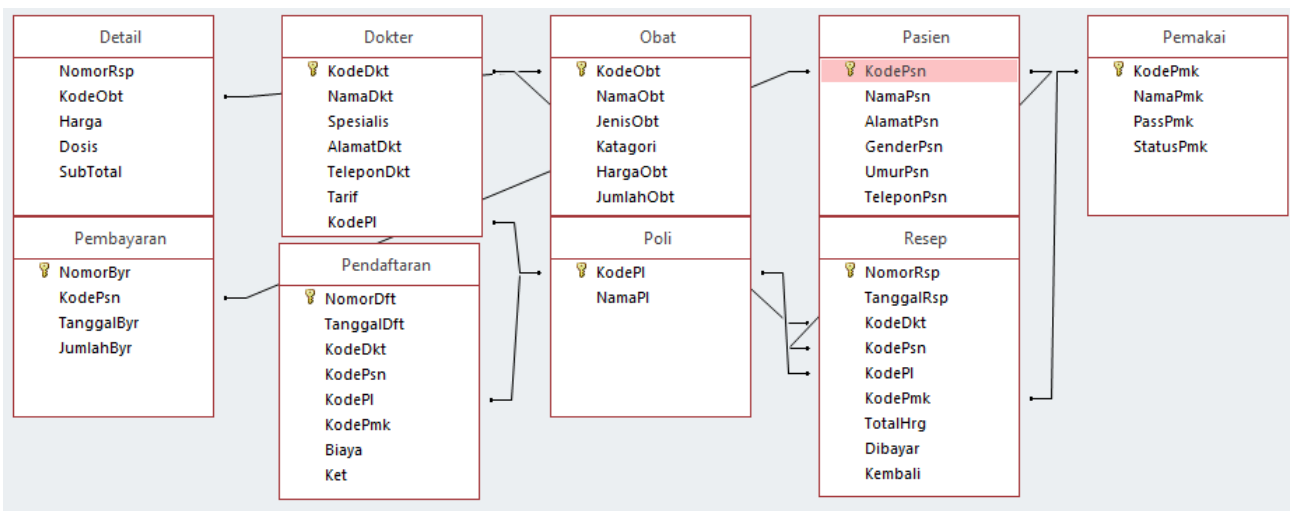

Gambar 9. Relasi Antar Tabel

Adapun hasil dari penelitian ini berupa sebuah aplikasi yang terdiri dari beberapa form yaitu; login, admin, input alat berat, penyewa, transaksi, dan user.

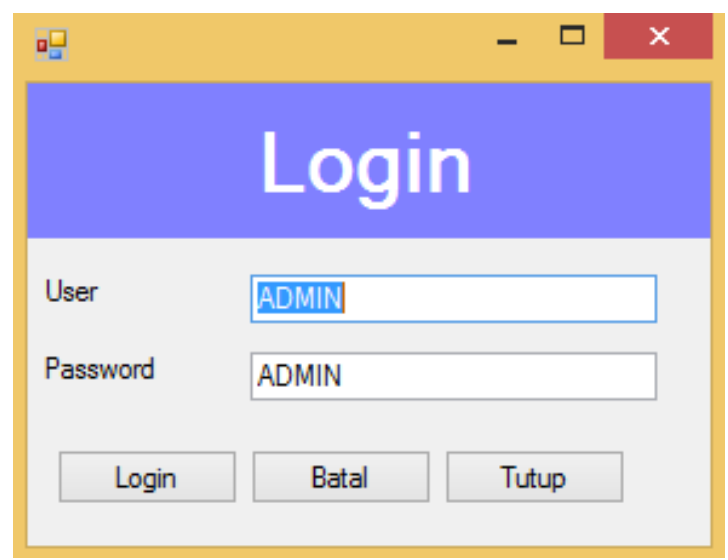

Gambar 10. Form Login 


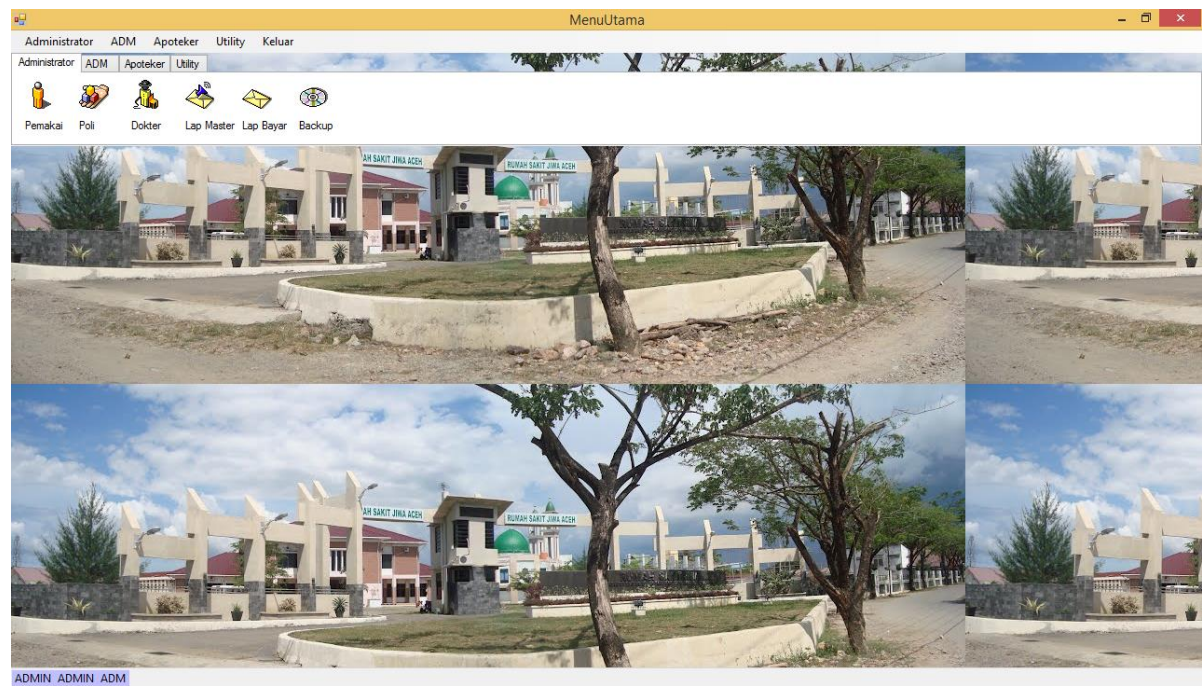

Gambar 11. Form Menu Utama Admin

\begin{tabular}{|c|c|c|c|c|c|}
\hline \multicolumn{2}{|l|}{ 吗 } & \multicolumn{2}{|r|}{ Pemakai } & - $\square$ & $\times$ \\
\hline \multicolumn{2}{|c|}{ Kode } & \multicolumn{2}{|l|}{ ADM01 } & & \\
\hline \multicolumn{2}{|c|}{ Nama } & \multicolumn{2}{|l|}{ HAWILAH } & & \\
\hline \multicolumn{2}{|c|}{ Password } & \multicolumn{2}{|l|}{ HAWILAH } & & \\
\hline \multicolumn{2}{|c|}{ Status } & \multicolumn{2}{|l|}{ ADM } & $v$ & \\
\hline \multicolumn{2}{|c|}{ Simpan } & Hapus & & \multicolumn{2}{|c|}{ Tutup } \\
\hline & \multicolumn{2}{|c|}{ KodePmk } & NamaPmk & PassPmk & $\hat{\wedge}$ \\
\hline \multirow[t]{4}{*}{ • } & \multicolumn{2}{|c|}{ ADM01 } & HAWILAH & HAWILAH & \\
\hline & \multicolumn{2}{|c|}{ APT01 } & RYAN & POLO & \\
\hline & \multicolumn{2}{|c|}{ USER } & USER & USER & \\
\hline & \multicolumn{2}{|c|}{ ADMIN } & ADMIN & ADMIN & \\
\hline \multicolumn{3}{|l|}{ <" } & & \multicolumn{2}{|c|}{$>$} \\
\hline
\end{tabular}

Gambar 12. Form Input User

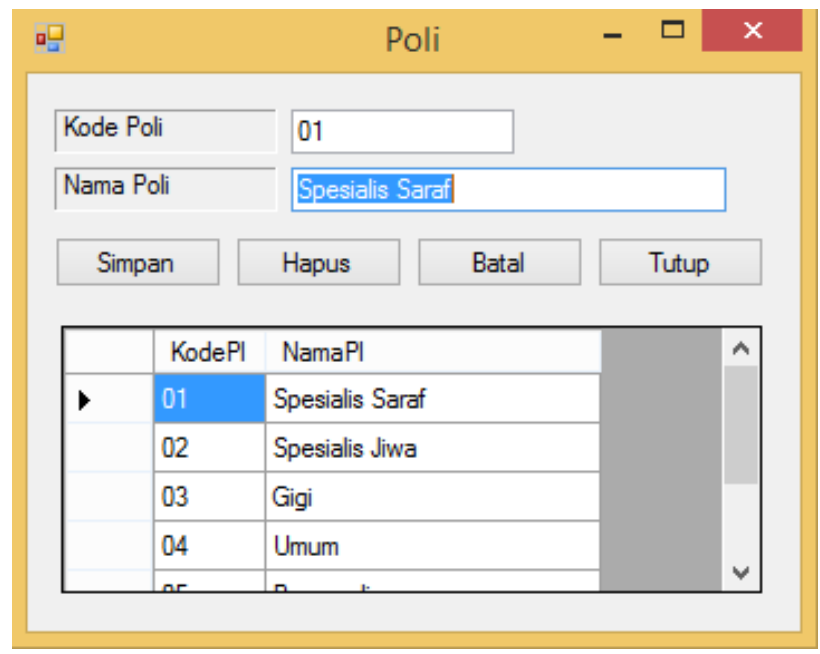

Gambar 13. Form Input Poli 


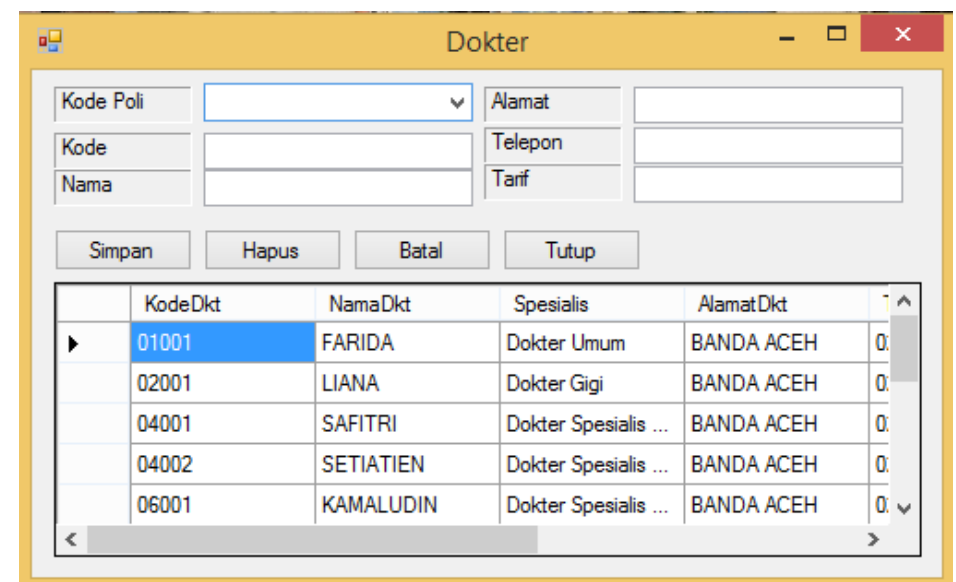

Gambar 14. Form Input Dokter

\begin{tabular}{|c|c|c|c|c|c|c|c|c|}
\hline \multicolumn{2}{|l|}{ 吗 } & \multicolumn{4}{|c|}{ Pendaftaran } & & - $\square$ & $\times$ \\
\hline \multicolumn{2}{|l|}{ Nomor } & \multicolumn{2}{|l|}{1610100001} & \multicolumn{2}{|c|}{ Kode Pasien } & \multicolumn{2}{|l|}{11082903} & $\checkmark$ \\
\hline \multicolumn{2}{|c|}{ Tanggal } & \multicolumn{2}{|l|}{$10 / 10 / 2016$} & \multicolumn{2}{|c|}{ Nama } & \multicolumn{2}{|l|}{ ALBANI } & \\
\hline \multicolumn{2}{|l|}{ Poli } & 02 MATA & $\checkmark$ & \multicolumn{2}{|c|}{ Alamat } & \multicolumn{3}{|l|}{ SIGLI } \\
\hline \multicolumn{2}{|c|}{ Nomor Antri } & & & \multicolumn{2}{|c|}{ Gender P/W } & \multicolumn{3}{|l|}{ PRIA } \\
\hline \multirow{3}{*}{$\begin{array}{l}02001 \\
02002\end{array}$} & \multirow{3}{*}{\multicolumn{2}{|c|}{$\begin{array}{l}\text { LIANA } \\
\text { PERTIWI }\end{array}$}} & & \multicolumn{2}{|c|}{ Umur } & \multicolumn{3}{|l|}{20} \\
\hline & & & & \multicolumn{2}{|c|}{ Telepon } & \multicolumn{3}{|c|}{021992277} \\
\hline & & & & \multicolumn{2}{|c|}{ Biaya Dokter } & & & \\
\hline \multicolumn{2}{|c|}{ Simpan } & Batal & \multicolumn{2}{|c|}{ Tutup } & \multicolumn{4}{|c|}{ Pasien Baru } \\
\hline & \multicolumn{2}{|c|}{ NomorDft } & \multicolumn{2}{|l|}{ TanggalDft } & \multicolumn{2}{|c|}{ KodeDkt } & KodePsr & $\wedge$ \\
\hline \multirow[t]{4}{*}{ 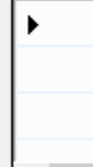 } & \multicolumn{2}{|c|}{1108290001} & \multicolumn{2}{|l|}{$8 / 29 / 2016$} & \multicolumn{2}{|c|}{01001} & 1108290 & \\
\hline & \multicolumn{2}{|c|}{1108290002} & \multicolumn{2}{|l|}{$8 / 29 / 2016$} & \multicolumn{2}{|l|}{02001} & 1108290: & \\
\hline & \multicolumn{2}{|c|}{1108290003} & $8 / 29 / 2016$ & & 05001 & & 1108290 & \\
\hline & $11 n$ & annna & nmomner & & namno & & 11กnาnก & $\checkmark$ \\
\hline$<$ & & & & & & & $>$ & \\
\hline
\end{tabular}

Gambar 15. Form Input Pendaftaran Pasien

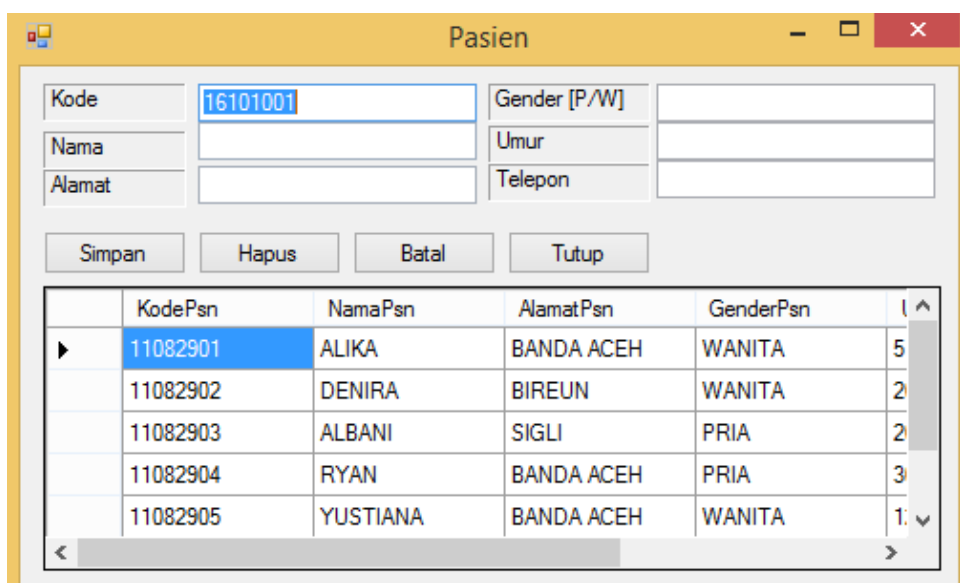

Gambar 16. Form Input Pasien 


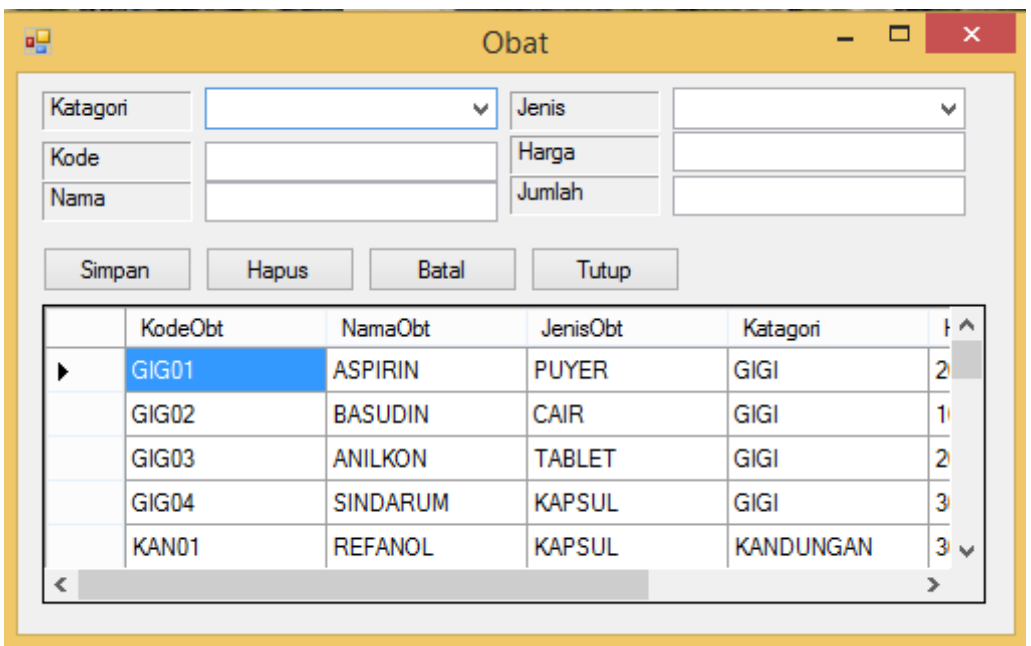

Gambar 17. Form Input Obat

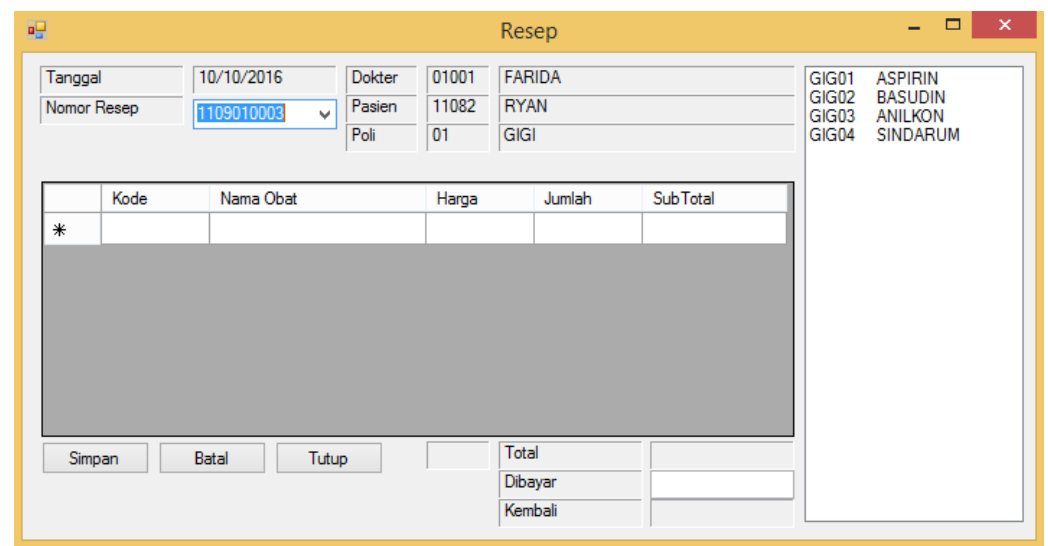

Gambar 18. Form Input Resep

Berikut ini adalah hardware dan software yang dibutuhkan untuk menggunakan program sistem pasien, yaitu:

\section{a. Hardware}

Hardware yang dapat mendukung aplikasi ini memerlukan perangkat keras dengan spesifikasi:

1. CPU minimal pentium 3 dengan kecepatan $633 \mathrm{Mhz}$

2. Ram $256 \mathrm{MB}$

3. Hard disk minimal 1 GigaByte

4. Monitor

5. Keyboard dan Mouse

6. Printer

\section{b. Software}

Software yang mendukung aplikasi ini diantaranya:

1. Windows $7,8,10$

2. Net. Framework 3,5

3. Crystal Report.

\section{Kesimpulan}

Dari hasil penelitian dan pengamatan yang telah dilakukan pada Rumah Sakit Jiwa (RSJ) Aceh, maka dapat diambil kesimpulan sebagai berikut : 
1. Dengan adanya Program Sistem Informasi pasien ini Sistem informasi pada Rumah Sakit Jiwa (RSJ) Aceh menjadi tepat, dan akurat khususnya pada bagian pasien. Dan untuk memperoleh informasi mengenai pasien tersebut menjadi lebih mudah.

2. Sistem informasi ini mampu mengatasi permasalahan yang sering terjadi pada Rumah Sakit Jiwa (RSJ) Aceh yaitu sulit dalam mengontrol dan mengawasi pasien dan perencanaan pengadaan barang. sistem informasi pengadaan barang ini dapat menghindari pasien berlebih dan mengatasi kelangkaan barang yang tentunya sangat di harapkan oleh pelaku usaha.

3. Terciptanya suatu program sistem informasi guna untuk memperoleh informasi yang berkualitas.

\section{Daftar Pustaka}

[1] Wardati, I.U., 2013. Sistem Informasi Pendaatan Pasien Pada Rumah Bersalin Dan Balai Pengobatan Pelayanan Kesejahteraan Umat (Pku) Muhammadiyah Batuwarno. IJNSIndonesian Journal on Networking and Security, 4(2).

[2] Ulya, H.N.M., 2020. Alternatif Strategi Penanganan Dampak Ekonomi Covid-19 Pemerintah Daerah Jawa Timur Pada Kawasan Agropolitan. El-Barka: Joumal of Islamic Economics and Business, 3(1), pp.80-109.

[3] MARDIANA, S., 2018. SISTEM INFORMASI RAWAT JALAN PADA KLINIK BERSALIN Dr. ENNY DENGAN MODEL WATERFALL (Doctoral dissertation, STMIK ATMA LUHUR).

[4] Pasaribu, J.S. and Sihombing, J., 2017. Perancangan Sistem Informasi Rekam Medis Pasien Rawat Jalan Berbasis Web Di Klinik Sehat Margasari Bandung. Jurnal Ilmiah Teknologi Infomasi Terapan, 3(3).

[5] Gunawan, Y.S., 2019. Sistem Informasi Administrasi Pelayanan Kesehatan Pada Puskesmas Nambo Banjaran Bandung (Doctoral dissertation, Universitas Komputer Indonesia).

[6] HASANUDDIN, H., 2017. Sistem Informasi Pelayanan Nikah Dan Rujuk Pada Kantor Urusan Agama (KUA) Kecamatan Cempaka (Doctoral dissertation, UIN RADEN FATAH PALEMBANG).

[7] Raihan, F.M., 2021. PERANCANGAN SISTEM INFORMASI REKAM MEDIS PADA KLINIK SAFFIRA SENTRA MEDIKA BATAM. Jurnal Sains, Aplikasi, dan Teknologi Informasi (SNATi), 1(1).

[8] Ramadhan, H., 2020. SISTEM INFORMASI MANAJEMEN UNTUK PELAYANAN PUBLIK (Studi Pada E-Puskesmas Di Puskesmas Pakisaji, Kecamatan Pakisaji, Kabupaten Malang (Doctoral dissertation, Universitas Brawijaya).

[9] Moerdani, R., 2021. Development of Dekstop Based Customer Data Information System (Case Study: PDAM Tirta Fulawan Siemeulue Barat). International Journal Software Engineering and Computer Science (IJSECS), 1(1), pp.34-48. 
[10] Sahruddin, S. and Salam, A., 2021. E-Library at Aceh Provincial Language Center. International Journal Education and Computer Studies (IJECS), 1(1), pp.1-7.

[11] Cahya, N., 2020. PERANCANGAN SISTEM INFORMASI ABSENSI KARYAWAN PADA KANTOR SATPOL PP DAN WH ACEH. Jurnal Indonesia: Manajemen Informatika dan Komunikasi, 1(2), pp.63-69.

[12] Iqbal, T., Aprizal, D. and Wali, M., 2017. Aplikasi Manajemen Persediaan Barang Berbasis Economic Order Quantity (EOQ).Jurnal JTIK Jurnal Teknologi Informasi dan Komunikasi), 1(1), pp.48-60.

[13] Wali, M. and Ahmad, L., 2018. Perancangan Access Open Journal System (AOJS) dengan menggunakan Framework Codeigniter dan ReactJs. Jurnal JTIK Jurnal Teknologi Informasi dan Komunikasi), 2(1), pp.48-56.

[14] Ismail, I. and AlBahri, F.P., 2019. Perancangan E-Kuisioner menggunakan CodeIgniter dan React-Js sebagai Tools Pendukung Penelitian.J-SAKTI Jurnal Sains Komputer dan Informatika), 3(2), pp.337-347.

[15] Kadafi, M., 2020. Sistem Informasi Pengolahan Data Transaksi Pada CV. Global Trans Solutions. Jurnal Indonesia: Manajemen Informatika dan Komunikasi, 1(1), pp.1-8.

[16] Ardiansyah, T., 2020. Sistem Informasi Pemesanan Tiket Pada CV. Global Trans Solutions. Jurnal Indonesia: Manajemen Informatika dan Komunikasi, 1(1), pp.9-19.

[17] Hasanah, U., 2020. Sistem Informasi Pendistribusian Barang Pada PT. Sampurna Sukses Utama Aceh Besar. Jurnal Indonesia: Manajemen Informatika dan Komunikasi, 1(1), pp.20-27. 